\title{
KEMAMPUAN PROSES PEMECAHAN MASALAH MATEMATIS SISWA MELALUI MODEL PEMBELAJARAN CREATIVE PROBLEM SOLVING DAN RESOURCE BASED LEARNING (STUDI EKSPERIMEN PADA SISWA KELAS X SMK KRIJA BHAKTI UTAMA LIMBANGAN)
}

\author{
Yopi Ahmad Sopian ${ }^{1}$, Ekasatya Aldila Afriansyah ${ }^{2}$ \\ ${ }^{1,2}$ STKIP Garut \\ e_satya@yahoo.com
}

\begin{abstract}
Abstrak
Salah satu aspek penting dalam pembelajaran matematika adalah kemapuan proses pemecahan masalah yang dapat diaplikasikan dalam kehidupan nyata. Tujuan dari penelitian ini untuk mengkaji hasil perbedaan kemampuan proses pemecahan masalah matematis siswa yang mendapatkan model Creative Problem Solving dan Resource Based Learning. Metode penelitian ini adalah kuasi eksperimen dengan Sampel populasi penelitian ini adalah siswa SMK Krija Bhakti Utama. Hasil dari penelitian ini adalah (1) Terdapat perbedaan kemampuan proses pemecahan masalah matematis siswa yang mendapatkan model Creative Problem Solving dan Resource Based Learning. (2) Peningkatan kemampuan proses pemecahan masalah yang diberi model Creative Problem solving adalah sedang. (3) Peningkatan kemampuan proses pemecahan masalah yang diberi model Resource Based Learning adalah rendah.
\end{abstract}

Kata kunci: Kemampuan proses pemecahan masalah matematis siswa, model Creative Problem Solving, model Resource Based Learning

Abstract

One of the important aspects in learning mathematics is problem-solving process ability that can be applied in real life. The purpose of this study is to assess the result of differences in the ability of students' mathematical problem-solving process ability that get the Creative Problem Solving and Resource Based Learning model. This research method is a quasi-experimental study; a sample population was students of SMK Bhakti Utama Krija. The results of this study were (1) There were differences students' mathematical problem-solving process ability to get the Creative Problem Solving and Resource Based Learning model. (2) Increasing problem-solving process ability by Creative Problem Solving model was moderate. (3) Increasing problem-solving process ability by Resource Based Learning model was low.

Keywords: Students' mathematical problem-solving process ability, Creative Problem Solving model, Resource Based Learning model.

\section{PENDAHULUAN}

Matematika merupakan salah satu bidang studi yang mendukung perkembangan ilmu pengetahuan dan teknologi. Matematika dianggap begitu penting karena konsep-konsep dalam matematika banyak digunakan dalam disiplin ilmu yang lainnya. Matematika selalu digunakan pada setiap jenjang pendidikan dan akan sangat membantu kelancaran proses 
belajar peserta didik apabila memahami konsep matematika dari tingkat yang paling dasar. Mata pelajaran matematika diberikan kepada siswa untuk membekali kemampuan berpikir logis, kritis, kreatif, dan inovatif. Selain itu, mata pelajaran matematika juga membekali siswa dalam kemampuan bekerja sama. Kompetensi tersebut diperlukan agar siswa dapat memiliki kemampuan memperoleh, mengelola, dan memanfaatkan informasi untuk bertahan hidup pada keadaan yang selalu berubah, tidak pasti, dan kompetitif (Depdiknas, 2006).

Salah satu tujuan belajar matematika menurut Peraturan Menteri Pendididkan Nasional Republik Indonesia Nomor 22 Tahun 2006 adalah untuk membekali siswa dengan kemampuan pemecahan masalah yang meliputi kemampuan memahami masalah, merancang model matematika, menyelesaikan model dan menafsirkan solusi yang diperoleh. Polya (Madawiah, 2008:241) mengemukakan "Pemecahan masalah sebagai suatu usaha mencari jalan keluar dari suatu kesulitan guna mencapai suatu tujuan yang tidak begitu segera dapat dicapai”. Pentingnya pemecahan masalah ini dinyatakan dalam salah satu rekomendasi National Council of Teacher of Mathematics tahun 1989 (Madawiah, 2008:242) yaitu "Pemecahan masalah harus menjadi fokus pada pembelajaran matematika untuk setiap jenjang sekolah".

Namun kenyataannya di Indonesia hasil belajar matematika siswa kelas 8 sangat rendah. Sebagaimana yang dikemukakan oleh Wardhani (Khususwanto, 2013:2):

Bahwa Indonesia telah mengikuti Trends In International Mathematics and Science Study (TIMSS) pada tahun 1999, 2003, 2007 dan Programme for International Student Asessment (PISA) tahun 2000, 2003, 2006, 2009 dengan hasil tidak menunjukan banyak perubahan pada setiap keikutsertaan. Pada Programme for International Student Asessment (PISA) tahun 2009 Indonesia hanya menduduki ranking 61 dari 65 peserta dengan rata-rata skor 371. Sementara rata-rata skor internasional adalah 496. Prestasi pada Trends In International Mathematics and Science Study (TIMSS) 2007 lebih memprihatinkan lagi, karena rata-rata skor siswa kelas 8 kita menurun menjadi 405, dibanding tahun 2003 yaitu 411. Ranking Indonesia pada TIMSS tahun 2007 menjadi ranking 36 dari 49 negara.

Seiring dengan perkembangan ilmu pengetahuan saat ini, banyak peneliti yang telah mengembangkan model-model pembelajaran yang dianggap dapat mengoptimalkan seluruh minat dan kemampuan peserta didik. Salah satu model pembelajaran yang menurut penulis dapat menjadi jawaban untuk memperoleh hasil yang sesuai dengan tujuan pendidikan nasional, adalah model Creative Problem Solving (CPS) dan model Resource Based Learning (RBL).

Menurut Pepkin (Meichika, 2014:2) mendefinisikan model CPS sebagai model pembelajaran yang memusatkan pada pengajaran dan keterampilan pemecahan masalah, yang diikuti dengan penguatan keterampilan. Menurut Madawiah (2008:220) Pendekatan ini 
merupakan variasi pembelajaran dengan pemecahan masalah melalui teknik sistematik dalam mengorganisasikan gagasan kreatif untuk menyelesaikan suatu permasalahan.

Sedangkan RBL menurut Nasution (Apriliana, 2015:484) adalah suatu proses pembelajaran yang langsung menghadapkan siswa dengan suatu atau sejumlah sumber belajar secara individual atau kelompok dengan segala kegiatan yang bertalian dengan sumber belajar. Berbeda dengan pembelajaran matematika konvensional dimana guru menyampaikan bahan pelajaran kepada siswa. Dari uraian-uraian mengenai kemampuan proses pemecahan masalah matematis, model CPS dan RBL maka peneliti terdorong untuk melaksanakan penelitian dengan judul: Perbedaan Kemampuan Proses Pemecahan Masalah Matematis Siswa antara yang Mendapatkan Model Pembelajaran Creative Problem Solving dan Resource Based Learning.

\section{Kemampuan Proses Pemecahan Masalah Matematis}

Pemecahan masalah adalah proses yang digunakan untuk menyelesaikan masalah. Setiap masalah tentu saja memerlukan cara penyelesaian yang berbeda-beda, salah satu di antaranya adalah melalui pemecahan masalah matematika. Izzati (Darliani, 2015:9-10) menyatakan bahwa "Pemecahan masalah matematis adalah mengerjakan tugas-tugas matematika yang cara menyelesaikannya belum diketahui sebelumnya, dan pemecahannya tidak dapat dilakukan dengan algoritma tertentu".

Menurut Wena (2011:52) "Pada dasarnya tujuan akhir pembelajaran adalah menghasilkan siswa yang memiliki pengetahuan dan keterampilan dalam memecahkan masalah yang dihadapi kelak di masyarakat". Kemampuan proses pemecahan masalah matematis yang dimaksud adalah kemampuan yang dimiliki siswa setelah memperoleh pembelajaran matematika, dalam menyelesaikan soal uraian yang diberikan untuk mencari alternatif penyelesaian masalah agar didapatkan suatu solusi untuk menyelesaikan permasalahan.

Dalam penelitian ini, indikator kemampuan proses pemecahan masalah yang digunakan adalah menurut Polya yang sudah direvisi peneliti sebagai berikut:

1. Mengidentifikasi unsur yang diketahui, langkah ini penting dilakukan sebagai tahap awal dari pemecahan masalah matematis agar siswa mudah dalam mencari penyelesaian masalah yang diajukan.

2. Perencanaan strategi penyelesaian masalah, langkah-langkah perencanaan ini penting dilakukan sebab ketika siswa mampu membuat suatu hubungan dari data yang diketahui dan yang tidak, maka siswa akan mudah menemukan penyelesaiannya. 
3. Penyelesaian Masalah, langkah ini dilakukan untuk melihat apakah siswa benar-benar memahami soal tersebut, selain itu untuk mengetahui apakah siswa dapat melihat penyelesaian yang dibuatnya sudah benar atau belum.

\section{Model Pembelajaran Creative Problem Solving}

Menurut Pepkin (Meichika, 2014:3) menyatakan bahwa "Model pembelajaran CPS adalah suatu metode pembelajaran yang melakukan pemusatan pada pengajaran dan keterampilan memecahkan masalah, yang diikuti dengan penguatan keterampilan”. Ketika dihadapkan dengan suatu permasalahan, siswa dapat melakukan ketrampilan memecahkan masalah untuk memilih dan mengembangkan tanggapannya. Tidak hanya dengan cara menghafal tanpa dipikir, keterampilan memecahkan masalah memperluas proses berpikir (Pepkin, 2004:03). Suatu soal yang dianggap sebagai "masalah" adalah soal yang memerlukan keaslian berpikir tanpa adanya contoh penyelesaian sebelumnya. Karen (Meichika, 2014:3) menuliskan langkah-langkah CPS dalam pembelajaran matematika sebagai hasil gabungan prosedur Von Oech dan Osborn, yaitu:

1. Klarifikasi masalah

2. Pengungkapan gagasan

3. Evaluasi dan seleksi

4. Implementasi

Berdasarkan beberapa langkah di atas, maka implementasi Creative Problem Solving dalam penelitian ini terdiri dari langkah-langkah sebagai berikut:

1. Kegiatan Awal

Guru menanyakan kesiapan siswa untuk mengikuti pelajaran, guru mengulas kembali materi sebelumnya sebagai prasyarat pada materi saat ini kemudian guru menjelaskan aturan main dalam pelaksanaan metode pembelajaran CPS serta memberi motivasi kepada siswa akan pentingnya pembahasan materi melalui pembelajaran CPS.

2. Kegiatan Inti

Siswa membentuk kelompok kecil untuk melakukan small discussion. Tiap kelompok terdiri atas 4-5 orang. Secara berkelompok, siswa memecahkan permasalahan yang disajikan sesuai dengan petunjuk yang tersedia. Siswa mendapat bimbingan dan arahan dari guru dalam memecahkan permasalahan (peranan guru dalam hal ini menciptakan situasi yang dapat memudahkan munculnya pertanyaan dan mengarahkan kegiatan brainstorming serta menumbuhkan situasi dan kondisi lingkungan yang dihasilkan atas 
dasar interest siswa). Adapun penekanan dalam pendampingan siswa dalam menyelesaikan permasalahan sebagai berikut:

a. Klarifikasi Masalah

Klarifikasi masalah meliputi pemberian penjelasan kepada siswa tentang masalah yang diajukan agar siswa dapat memahami tentang penyelesaian seperti apa yang diharapkan.

b. Brainstorming/ Pengungkapan pendapat

Pada tahap ini siswa dibebaskan untuk mengungkapkan pendapat tentang berbagai macam strategi penyelesaian masalah, tidak ada sanggahan dalam mengungkapan ide gagasan satu sama lain.

c. Evaluasi dan Seleksi

Pada tahap ini, setiap kelompok mendiskusikan pendapat-pendapat atau strategistrategi mana yang cocok untuk menyelesaikan masalah.

d. Implementasi

Pada tahap ini, siswa menentukan strategi mana yang dapat diambil untuk menyelesaikan masalah kemudian menerapkannya sampai menemukan penyelesaian dari masalah tersebut.

\section{Kegiatan Akhir}

Lebih lanjut, perwakilan dari masing-masing kelompok mempresentasikan hasil yang telah didiskusikan ke depan kelas dan peserta lain menanggapinya. Kemudian guru bersama siswa menyimpulkan hasil diskusi.

Setiap model pembelajaran tetap mempunyai kelebihan maupun kekurangan, begitu juga dengan model Creative Problem Solving. Mayasa (2012:2) mengemukakan kelebihan dan kekurangan model pembelajaran Creative Problem Solving. Adapun kelebihannya yaitu:

1. Melatih siswa untuk mendesain suatu penemuan.

2. Berpikir dan bertindak kreatif.

3. Memecahkan masalah yang dihadapi secara realistis.

4. Mengidentifikasi dan melakukan penyelidikan.

5. Menafsirkan dan mengevaluasi hasil pengamatan.

6. Merangsang perkembangan kemajuan berfikir siswa untuk menyelesaikan masalah yang dihadapi dengan tepat.

7. Dapat membuat pendidikan sekolah lebih relevan dengan kehidupan, khususnya dunia kerja. 
Sedangkan kekurangan Creative Problem Solving sebagai berikut:

1. Beberapa pokok bahasan sangat sulit untuk menerapkan metode pembelajaran ini. Misalnya keterbatasan alat-alat laboratorium menyulitkan siswa untuk melihat dan mengamati serta menyimpulkan kejadian atau konsep tersebut.

2. Memerlukan alokasi waktu yang lebih panjang dibandingkan dengan metode pembelajaran yang lain.

\section{Model Pembelajaran Resource Based Learning}

Resource Based Learning adalah suatu proses pembelajaran yang langsung menghadapkan siswa dengan suatu atau sejumlah sumber belajar secara individual atau kelompok dengan segala kegiatan yang bertalian dengan sumber belajar (Sagala, 2010:65). Resource Based Learning tidak meniadakan peranan guru, juga tidak berarti bahwa guru dapat duduk bermalas-malasan. Guru terlibat dalam setiap langkah proses belajar, dari perencanaan, penentuan dan mengumpulkan sumber-sumber informasi, memberi motivasi, memberi bantuan apabila diperlukan dan bila dirasanya perlu memperbaiki kesalahan (Windaningsih, 2015: 13).

Jadi dalam Resource Based Learning guru bukan merupakan sumber belajar satusatunya. Siswa dapat belajar dalam kelas, dalam laboratorium, dalam perpustakaan, dalam "ruang sumber belajar" yang khusus atau bahkan di luar sekolah, bila ia mempelajari lingkungan berhubungan dengan tugas atau masalah tertentu. Dalam melakukan tugas yang bebas berdasarkan tekhnik pemecahan masalah, penemuan, dan penelitian, bergantung kepada keputusan guru serta kemungkinan yang ada dalam rangkaian kurikulum yang berlaku di sekolah.

Windaningsih (2015:16-17) mengemukakan langkah-langkah pembelajaran Resource Based Learning sebagai berikut:

1. Guru melaksanakan pembelajaran matematika dengan menggunakan model Resource Based Learning.

2. Pengenalan materi matematika dan penyelesaiannya.

3. Guru memberikan contoh soal dan cara mengembangkannya menjadi sub-sub pertanyaan dan penyelesaiannya.

4. Siswa dikelompokkan masing-masing 5 atau 6 orang secara heterogen.

5. Pembelajaran diawali dengan permasalahan yang ada di LKS.

6. Siswa mengamati permasalahan, mengembangkan minat dan gagasan untuk menemukan konsep awal dalam proses pembelajaran. 
7. Siswa diberi kesempatan untuk mengajukan pertanyaan dan permasalahan.

8. Masing-masing siswa berusaha menyelesaikan permasalahan secara individu.

9. Hasil pemecahan masalah sendiri kemudian disharingkan dalam kelompok.

10. Guru membimbing, mengawasi, dan membantu siswa yang mengalami kesulitan menyelesaikan masalah matematika.

11. Siswa menuliskan hasil diskusi kelompok ke dalam lembar hasil diskusi.

12. Masing-masing kelompok yang telah selesai melakukan diskusi harus melaporkan kerja kelompoknya kepada guru.

13. Diskusi kelompok bertukar pendapat, wawasan, dan temuan hasil penyelesaian untuk menyepakati semua kesepahaman.

14. Guru menegaskan kembali hasil diskusi yang telah disajikan siswa.

15. Guru melakukan evaluasi terhadap hasil diskusi siswa.

16. Kuis.

Berdasarkan pembahasan mengenai Resource Based Learning di atas, maka dalam penelitian ini menggunakan langkah-langkah sebagai berikut:

1. Guru mengelompokan siswa menjadi beberapa kelompok.

2. Guru memaparkan materi yang akan di diskusikan.

3. Guru memberikan permasalahan kepada siswa melalui lembar kerja siswa

4. Guru memberikan informasi mengenai sumber belajar yang dapat digunakan untuk menyelesaikan permasalahan.

5. Siswa saling berdiskusi dalam kelompoknya untuk menyelesaikan permasalahan.

6. Guru berkeliling ke setiaap kelompok untuk mengecek kondisi setiap kelompok dan membantu kesulitan siswa.

7. Perwakilan setiap kelompok mempresentasikan hasil diskusi.

8. Guru mengevaluasi hasil diskusi.

9. Guru memberi penguatan melauli pemberian kuis.

\section{METODE}

Metode yang digunakan pada penelitian ini adalah metode kuasi eksperimen. Desain yang digunakan dalam penelitian ini adalah jenis desain The Static Group Pretest-Posttest Design. Adapun desain dalam penelitian ini adalah sebagai berikut:

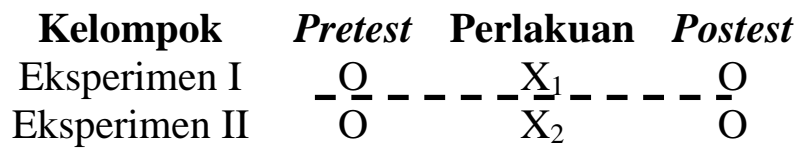


Keterangan :

$\mathrm{O}=$ Tes awal (pretest) dan tes akhir (posttest)

$\mathrm{X}_{1}=$ Pembelajaran menggunakan CPS.

$\mathrm{X}_{2}=$ Pembelajaran menggunakan RBL.

Populasi yang diambil pada penelitian ini yaitu seluruh siswa kelas X SMK Krija Bhakti Utama Limbangan Tahun ajaran 2015-2016. Sedangkan sampel dari penelitian ini adalah X Otomotif 1 sebagai kelas eksperimen I dengan jumlah siswa 38 orang dan X Otomotif 2 sebagai kelas eksperimen II dengan jumlah siswa 36 orang. Penelitian ini dilaksanakan pada tanggal 8 April sampai dengan 10 Mei 2016 di SMK Krija Bhakti Utama Limbangan.

Instrumen dalam penelitian ini adalah instrumen tes tertulis. Instrumen tes yang dilakukan adalah dua bentuk tes yaitu tes awal (Pretest) dan tes akhir (Posttest) dengan bentuk soal yang sama. Analisis data dilakukan dengan menggunakan perhitungan statistik, dimulai dari uji coba instrumen, analisis data pretest dan analisis data posttest.

\section{HASIL DAN PEMBAHASAN}

\section{Hasil Penelitian}

\section{Deskripsi Hasil Penelitian}

Analisis data pre-test dilakukan untuk mengetahui kemampuan awal siswa kelas CPS dan kelas RBL sebelum diberikan perlakuan pada proses pembelajaran. Adapun hasil perhitungan data pre-test dapat dilihat dalam tabel 1 berikut:

Tabel 1. Deskripsi Data Hasil Tes Awal

\begin{tabular}{cccccc}
\hline Kelas & n & Rata-rata & Skor Terbesar & Skor Terkecil & Simpangan Baku \\
\hline CPS & 38 & 17,24 & 26 & 8 & 3,72 \\
\hline RBL & 36 & 17,56 & 24 & 13 & 2,83 \\
\hline
\end{tabular}

Keterangan: Skor Ideal $=50$

Analisis data post-test dilakukan untuk menguji hipotesis penelitian yaitu perbedaan kemampuan proses pemecahan masalah matematis siswa antara kelas CPS dan kelas RBL setelah diberikan perlakuan pada proses pembelajaran. Adapun hasil perhitungan data posttest dapat dilihat dari tabel 2 berikut:

Tabel 2. Deskripsi Data Hasil Tes Akhir

\begin{tabular}{cccccc}
\hline Kelas & n & Rata-rata & Skor Terbesar & Skor Terkecil & Simpangan Baku \\
\hline CPS & 38 & 27,34 & 35 & 18 & 4,80 \\
\hline RBL & 36 & 24,08 & 31 & 17 & 3,69 \\
\hline
\end{tabular}

Keterangan: Skor Ideal $=50$ 


\section{Analisis Statistik dan Uji Hipotesis}

\section{Analisis Data Pre-Test}

Data hasil pre-test diperoleh dari rata-rata kelas CPS dan RBL masing-masing adalah 17,24 dan 17,56, sedangkan simpangan baku dari masing-masing kelas adalah 3,72 dan 2,83.

Kemudian dilakukan uji normalitas menggunakan Uji Lilliefors dengan hasil kelas CPS mempunyai nilai $L_{\text {maks }}=0,0779<L_{\text {tabel }}=0,1457$, sehingga data berdistribusi normal. Sedangkan pada kelas RBL mempunyai nilai $L_{\text {maks }}=0,1340<L_{\text {tabel }}=0,1498$, sehingga data berdistribusi normal. Selanjutnya dilakukan Uji homogenitas dua varians dan diperoleh $F_{\text {hitung }}=1,7279<F_{\text {tabel }}=1,7477$ sehingga kedua varians homogen. Karena kedua kelas berdistribusi normal dan homogen, maka dilanjutkan dengan Uji t.

Hasil Uji $\mathrm{t}$ diperoleh nilai $t_{\text {hitung }}=-0,4148<t_{\text {tabel }}=1,9934$, sehingga $\mathrm{H}_{0}$ diterima. Dengan demikian dapat disimpulkan bahwa tidak terdapat perbedaan kemampuan awal proses pemecahan masalah matematis siswa yang signifikan antara kelas CPS dan RBL.

\section{Analisis Data Post-Test}

Data hasil post-test diperoleh dari rata-rata kelas CPS dan RBL masing-masing adalah 27,34 dan 24,08, sedangkan simpangan baku dari masing-masing kelas adalah 4,80 dan 3,69. Kemudian dilakukan uji normalitas menggunakan Uji Lilliefors dengan hasil kelas CPS mempunyai nilai $L_{\text {maks }}=0,0818<L_{\text {tabel }}=0,1457$, sehingga data berdistribusi normal. Sedangkan pada kelas RBL mempunyai nilai $L_{\text {maks }}=0,0758<L_{\text {tabel }}=0,1498$, sehingga data berdistribusi normal. Selanjutnya dilakukan Uji homogenitas dua varians dan diperoleh $F_{\text {hitung }}=1,6921<F_{\text {tabel }}=1,7477$ sehingga kedua varians homogen. Karena kedua kelas berdistribusi normal dan homogen, maka dilanjutkan dengan Uji t.

Hasil Uji t diperoleh nilai $t_{\text {hitung }}=3,2624>t_{\text {tabel }}=1,9934$, sehingga $\mathrm{H}_{0}$ ditolak dan $\mathrm{H}_{\mathrm{a}}$ diterima. Dengan demikian dapat disimpulkan bahwa terdapat perbedaan kemampuan proses pemecahan masalah matematis siswa antara yang mendapatkan model pembelajaran $C P S$ dan RBL.

\section{Analisis Uji Gain Ternormlisasi}

Uji gain ternormalisasi digunakan untuk mengetahui peningkatan pencapaian kemampuan proses pemecahan masalah matematis siswa yang mendapatkan model CPS dan RBL. 
Adapun hasil uji gain ternormalisasi tersebut dapat dilihat dalam tabel 3 berikut:

Tabel 3. Rekapitulasi Uji Gain Ternormalisasi

\begin{tabular}{cccc}
\hline Kelas & $\boldsymbol{f}_{\boldsymbol{i}}$ & Rata-rata & Keterangan \\
\hline $\mathrm{CPS}$ & 38 & 0,30 & Sedang \\
\hline RBL & 36 & 0,15 & Rendah \\
\hline
\end{tabular}

\section{Pembahasan}

\section{Kemampuan Proses Pemecahan Masalah}

Berdasarkan analisis data hasil pre-test kelas CPS dan RBL diperoleh kesimpulan bahwa tidak terdapat perbedaan kemampuan awal proses pemecahan masalah siswa yang signifikan antara kelas CPS dan RBL. Sehingga langkah untuk menguji hipotesis penelitian dilakukan dengan cara menganalisis data hasil post-test.

Setelah dilakukan analisis data hasil post-test diperoleh kesimpulan bahwa terdapat perbedaan kemampuan proses pemecahan masalah matematis siswa antara yang mendapatkan model pembelajaran CPS dan RBL.

\section{Pelaksanaan Pembelajaran}

Proses pembelajaran dengan CPS dan RBL secara umum membuat siswa menjadi lebih senang dan bersemangat dalam mengikuti pelajaran. Akan tetapi pada saat peneliti melaksanakan pembelajaran dengan menggunakan kedua model pembelajaran ini, peneliti merasakan adanya beberapa kendala pada keduanya. Seperti pada kelas CPS, siswa belum mampu terlihat berdiskusi dalam kelompoknya, belum ada keterikatan kelompok untuk mengerjakan, saling bekerjasama, saling membantu, dan bertukar pendapat dalam kelompoknya, sehingga masalah seperti itu dapat mempengaruhi pada waktu pembelajaran. Sedangkan pada kelas RBL terlihat siswa belum mampu mencari solusi dari setiap permasalahan yang dihadapinya dari berbagai sumber yang digunakan, serta terlihat kurang kebersamaan dengan anggota kelompoknya, disebabkan siswa belum terbiasa dengan suasana baru dan aktifitas baru dalam pelajaran matematika dengan menggunakan pembelajaran CPS dan RBL.

\section{SIMPULAN}

Berdasarkan rumusan masalah dan hasil analisis data yang telah dilakukan dalam penelitian ini, maka dapat diambil kesimpulan bahwa: (1) Terdapat perbedaan kemampuan proses pemecahan masalah matematis siswa yang mendapatkan model CPS dan model RBL, (2) Peningkatan 
kemampuan proses pemecahan masalah pada kelas eksperimen I yang diberi model CPS adalah sedang, dan (3) Peningkatan kemampuan proses pemecahan masalah kelas kelas eksperimen I yang diberi model RBL adalah rendah.

Penulis menyadari bahwa masih banyak kekurangan dalam penelitian ini, walaupun demikian diharapkan penelitian ini dapat memberikan sumbangan yang berarti dalam peningkatan kemampuan pemecahan masalah matematis siswa. Berdasarkan dari penelitian yang dilakukan, dapat disarankan bahwa: (1) Penelitian terhadap model pembelajaran CPS dan RBL ini disarankan untuk dilanjutkan dengan aspek penelitian yang lain pada kajian yang lebih luas, agar dapat mengeksplorasi tahapan demi tahapan model pembelajaran ini sehingga mendapatkan hasil yang maksimal, dan (2) Siswa disarankan dapat lebih fokus dalam setiap pembelajaran dan dapat beradaptasi dengan berbagai model pembelajaran yang diterapkan dalam proses pembelajaran.

\section{DAFTAR PUSTAKA}

Apriliana, dkk. (2015). Elektronik Pembelajaran Matematika. (Online), (http://jurnal.fkip.uns.ac.id, 28 desember 2015).

Darliani, R. (2015). Meningkatkan Kemampuan Pemecahan Masalah Matematis Siswa Melalui Model Pembelajaran Meands Ends Analysis (MEA). Garut: STKIP Garut.

Depdiknas. (2006) Peraturan mentri Pendidikan nasioanal RI No.22 Tahun 2006 Tentang Standar Isi kurikulum Pendidikan Dasar dan Menengah. Jakarta: Depdiknas.

Khususwanto. (2013). Pembelajaran Matematika Dengan Pendekatan Resource Based Learning Untuk Meningkatkan Kemampuan Berpikir Kreatif Matematis Dan Self Confidence Siswa SMP. (Skripsi, Universitas Pendidikan Indonesia, 2013). (Online), (http://repository.upi.edu, 28 Januari 2016).

Madawiah (2008). Model-Model Pembelajaran [Diktat Kuliah]. Naskah, UIN Bandung: Tidak diterbitkan.

Mayasa.(2012). Metode Pembelajaran Creative Problem Solving. (Online), (http://m4ya5a.blogspot.co.id, 28 Desember 2015).

Meichika, dkk. (2014). Pengaruh Model Pembelajaran Coverative Problem solving. Tidak diterbitkan.

Pepkin, dkk. (2004). Creative Problem Solving in Match. (Online), (http://www.edu/hti/2004/v02/04html, 28 Desember 2015).

Sagala, S. (2010). Konsep dan Makna Pembelajaran. Bandung: Alfabeta.

Wena, M. (2011). Strategi Pembelajaran Inovatif Kontemporer: Suatu Tinjauan Konseptual Operasional. Jakarta: Bumi Aksara.

Windaningsih (2015). Perbedaan Kemampuan Pemecahan Masalah Matematis antara Siswa yang Mendapatkan Model Resource Based Learning (RBL) dengan Problem Based Learning (PBL). Garut: STKIP Garut. 